Tips om medisinsk litteratur, andre bøker, filmer og elektroniske medier som bør anmeldes, sendes tidsskriftet@legeforeningen.no

\section{Viktige, men ubearbeidede innspill}

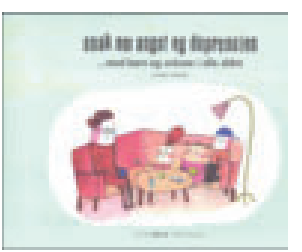

Karen Glistrup

\section{Snak om angst og depression}

med børn og voksne i alle aldre. 48 s, ill.

Risskov: Psyklnfo Forlaget, 2011.

Pris DKK 125

ISBN 978-87-994320-0-4

Forfatteren har faglig bakgrunn som sosialrådgiver, med diverse tilleggsutdanninger innen familieterapi og veiledning. Basert på erfaringer fra familiesamtaler, hvor også barna opplever å bli sett, ønsker hun her å nå så vel barn i alderen $0-6$ år, eldre barn og alle voksne med eller uten profesjonell helsefaglig bakgrunn. Hovedtemaet er knyttet til ønsket om å formidle viten og bryte ned tabuer knyttet til psykisk sårbarhet og sykdom generelt, ikke minst hos barn og unge som opplever dette i egen familie. Det er et viktig og stadig aktuelt tema.

Boken er delt i 13 kapitler, men overskriftene følger ikke alltid innholdslisten. Av leserveiledningen på baksiden av omslaget fremgår det at illustrasjonene til Pia Olsen er beregnet på alle. Det er enkle strektegninger av mennesker med varierte ansiktsuttrykk i ulike sitasjoner. Tekstene under tegningene og i venstre spalte på høyre side er for lesekyndige skolebarn, mens i høyre spalte på farget bakgrunn er teksten beregnet for voksne.

Hovedsakelig dreier det seg om tanker og følelser, psykiske lidelser, glede og smerte og om det gode liv mellom mennesker. En viktig intensjon for forfatteren, og hennes støttespillere innen Børnerådet, Psykiatrifonden og SINDs Pårørenderådgivning, er å formidle at det kan hjelpe å snakke om det hvis voksne har det «skitt» uten at barna forstår hvorfor. Her er det en rekke gode eksempler på symptomer og atferd ved psykiske lidelser og hvordan barn kan observere og reagere på dette. Beklageligvis er en rekke av forfatterens beskrivelser, bl.a. av det biopsykososiale grunnlaget for angst og depresjon eller hjernens funksjon, svært lite informative. $\AA$ sammenlikne hjernen med medisterpølser og datamaskiner virker som et lite faglig og litt krampaktig forsøk på å gjøre vanskelig stoff morsomt og interessant. I stedet blir det heller nokså løsrevet og mer forvirrende enn opplysende. Boken har ingen litteraturliste, men henvisning til 12 danske hjemmesider på nett.

Jeg undrer meg også over at forfatteren både i tittel og fremstilling legger så stor vekt på det å snakke, mens hun først på side 32 tydelig sier at «Det hjælper å tale med en som er god til å lytte og forstå». Rådene til de voksne om å snakke med barn tar heller ikke høyde for hvor viktig det er å ta hensyn til barns konkrete tenkning ved valg av ord og uttrykk i samtalene.

Kort sagt: Dette er en bok med en ambisiøs målsetting og mange gode forslag og innspill, både i form av tegninger og tekst om viktige og ofte forsømte temaer knyttet til psykiske lidelser i familiekontekst. Boken kan sikkert tjene som inspirasjon for dem som ønsker å bidra til bedre forståelse og mestring av slike utfordringer, men den vil profittere på en redaksjonell bearbeiding og en mer kunnskapsbasert og pedagogisk fremstilling, bl.a. av det biologiske grunnlaget for hjernen og kroppens funksjon i samspill med omgivelsene.

\section{Intressant om förebyggande hälsoarbete}

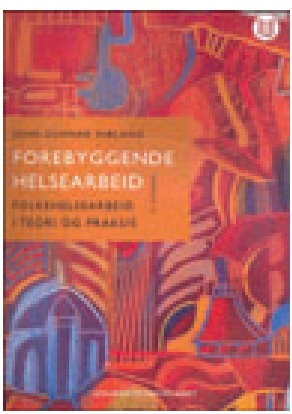

John Gunnar Mæland

Forebyggende helsearbeid

Folkehelsearbeid i teori og praksis. 3. utg.

234 s, ill. Oslo: Universitetsforlaget, 2010.

Pris NOK 389

ISBN 978-82-15-01608-5

John Gunnar Mæland har på Universitetsförlaget presenterat den tredje utgåvan av Forebyggende helsearbeid. Han öppnar med att ge en vid definition av vad som egentligen utgör förebyggande hälsoarbete: Det handlar inte bara om att förhindra sjukdom, skada och förtidig död (disease prevention). Det omfattar också det hälsofrämjande arbetet (health promotion), till exempel så som det presenterats av Världshälsoorganisationen (WHO). WHO har givit oss en utopisk hälsodefinition av fullständigt och optimalt fysiskt, mentalt och socialt välbefinnande. Man medger dock att en sådan utopisk definition kan göra mer skada än nytta på grund av sin ouppnåelighet. I stället har man fokuserat hälsobegreppet på möjligheten att leva ett ekonomiskt och socialt produktiv liv.

Med dessa inledande resonemang har Mæland skapat både bredd och djup för sitt ämne, så att han kan utnyttja de möjligheter ämnet ger. I 18 kapitel på 229 sidor, med ett trettiotal figurer, med avslutande sakregister, register över användbara nätadresser samt norska aktörer, myndigheter, institutioner och forskare inom det förebyggande hälsoarbetet, får ämnet bäde bredd och djup.

Han börjar med en beskrivning av hälsans och hälsoarbetets historia från 1900-talets början fram till vår tid. I sin första figur har han i princip inkluderat alla de begrepp som han i följande kapitel kommer att behandla, från hygien och hälsoupplysning till miljöarbete och beteendepåverkan (atferdspåvirkning).

Hälsolägets spektakulära förbättring under samma tid är dock bara till del avhängigt av det förebyggande hälsoarbetet. Till exempel ökade medellivslängden från ca. 50 år för män och kvinnor som levde vid 1900-talets början till 80 år för kvinnor och 76 för män, som levde vid dess slut, en ökning med 60 procent på hundra år.

Andra intressanta och användbara mått för att mäta hälsa är åldersrelaterad dödlighet, spädbarnsdödlighet och standardiserad mortalitetsratio (SMR). Det senare måttet utgör dödligheten hos en viss definierad grupp, till exempel lägsta socialklassen i relation till (eller standardiserad mot) dödlighet i befolkningen. Men det är ju inte bara dödsfallen i olika åldrar och olika kategorier som påverkar och ger en bild av hälsoläget. Även livskvaliteten, tillfredsställelsen och lyckan under den tid vi lever, har stor betydelse. Ett nydanande arbete har lagts ned på att ta fram ett integrerat mått på god hälsa, omfattande såväl antal levnadsdagar och år, som innehållet i dess dagar och år. Begreppet kallas kvalitetsjusterade levnadsår - QUALY (quality adjusted life years). För dem som lider av sjukdom eller handikapp, har man konstruerat ett motsvarande mått - DALYs (disability adjusted life years). Båda måtten beskriver i kvantitativa termer det hälsoutfall man finner i vissa grupper och hos vissa individer. 